\begin{tabular}{lllll} 
ZAPISKI HISTORYCZNE & $-\underset{\text { Zeszyt } 4}{\text { TOM }}$ & LXXX & - ROK 2015 \\
\hline
\end{tabular}

http://dx.doi.org/10.15762/ZH.2015.53

ANNA ŁYSIAK-ŁĄTKOWSKA

(University of Gdańsk)

\title{
ALPHONSE FORTIA DE PILES AND LOUIS DE BOISGÉLIN DE KERDU - EMIGRANTS TRAVELLING IN GERMAN COUNTRIES AND DENMARK AT THE END OF THE $18^{\mathrm{TH}}$ CENTURY
}

Keywords: emigrants, account, travelling conditions, roads, collections, libraries, palaces, castles

Alphonse Fortia de Piles and Louis de Boisgélin de Kerdu were aristocrats with royalist beliefs serving in the same garrison in $\mathrm{Nancy}^{1}$. Wanting to avoid the monotony and boredom of the military life, they invented the pseudonym de Caillot-Duval which they used to write Mystifications de Caillot-Duval, and to publish the re-print of the book in 1795 under a slightly modified title 2 .

Owing to their background and beliefs, after the outbreak of the revolution in 1789 they left France and remained abroad for a few years. As emigrants they visited various European countries including the Rzeczpospolita [the Polish-Lithuanian Commonwealth] in the last years of its existence ${ }^{3}$. They represented the type of emigrants who did not look for shelter at the courts - enemies of revolutionary France, conspired or were convinced that the world of old aristocratic France would survive. Instead, they were interested in other cultures, customs and habits; they travelled all around Europe and did not stop anywhere for a longer time ${ }^{4}$. The first of the mentioned authors of the travelogue returned to France after the

${ }^{1}$ Zbigniew AnUsik, Dyplomacja szwedzka wobec kryzysu monarchii we Francji w latach 1787-1792, Łódź 2000, pp. 303-308.

${ }^{2}$ See Correspondance philosophique de Caillot Duval rédigée d'après les pièces originales, et publiée par une Société de littérateurs lorrains Nancy, Nancy-Paris 1795; Les mystifications de Caillot-Duval: avec un choix de ses lettres les plus étonnantes, suivies des réponses de ses victimes, introd. et éclaircissements par Lorédan LARCHEY, Paris 1864, pp. I-XV.

${ }^{3}$ [Alphonse de] Fortia de Piles, [Louis De] Boisgélin de Kerdu, Podróż dwóch Francuzów, [in:] Polska stanisławowska w oczach cudzoziemców, vol. 2, ed. Wacław ZAWADZKI, Warszawa 1963, pp. 677-727.

${ }^{4}$ Bernhard Struck, Nie Zachód, nie Wschód. Francja i Polska w oczach niemieckich podróżnych w latach 1750-1850, transl. Zdzisław OwCZAReK, Róża Zielnik KoŁodzińska, Warszawa 2012, p. 63. About travelling traditions comp. Eric J. LeED, The Mind of the Traveler: From Gilgamesh to Global Tourism, New York 1991. 
death of Maximilien Robespierre and remained loyal to his royalist beliefs until his death in 1826. He represented a kind of man of the world who was familiar with literature and theatre and who himself created literary works. The other author came back to his country after the restoration of the Bourbons and soon after this he died at home in Brittany ${ }^{5}$.

The aftermath of their migration was Voyage de deux Français en Allemagne, Danemark, Suède, Russie et Pologne, fait en 1790-1792 ${ }^{6}$ published in Paris in 1796. It was a collection of a few volumes of accounts from their sojourn in various countries. They included descriptions of German territories, Denmark, Sweden, Austria, Russia and Poland. The first volume includes description of their journey through German territories and Denmark. All the countries visited by them were in Northern Europe. The definition of the north used until the end of the $18^{\text {th }}$ century as a geographical perspective constituted a criterion defining the division in terms of civilisation and space determined by conditions in those countries in political, economic and cultural areas. In the consciousness of the inhabitants of West Europe, it remained and exotic area, a mystery, even a fairy country made of ice and snow hiding its wilderness, terror and barbarity behind the white curtain of mystique ${ }^{7}$.

Voyage de deux Français $^{8}$ had two authors, but it was compiled by one of the travellers - Alphonse Fortia de Piles. As he wrote in the introduction, they collected the material which constituted the foundation for the final outcome of their journey and cooperation together with Louis de Boisgélin de Kerdu. Thus, the work is considered to have two authors: "ce voyage nété pas rédigé que par l'une de deux, sur le matériaux qu'elles ont recueillis ensemble, ainsi le corps l'Ouvrage est écrit au nom des deux voyageurs"'.

Voyage de deux Français included information concerning the history and economic development of the places visited along with some useful information and practical guidelines for potential travellers, which was one of the main aims of the publication. As the author of the introduction wrote, the publication was to constitute a form of a guidebook for those who would visit the depicted countries: "jai voulu servir de guide à ceux qui visiteront après moi les mêmes pays". The information included in it was to serve mainly other Frenchmen. It resulted from the belief that they were not acquainted enough with the conditions of travelling, unaware of the specificity of the countries which were situated off the beaten track from the most common routes for tourists at that time. Due to a lack of knowledge concerning the customs of such countries, their geographical, economic and historical

${ }^{5}$ Les mystifications de Caillot-Duval, pp. X-XI.

${ }^{6}$ Alphonse-Marie Fortiade de Piles, Louis de Boisgélin de Kerdu, Voyage de deux Français en Allemagne, Danemark, Suède, Russie et Pologne, fait en 1790-1792, vol. 1-5, Paris 1796.

${ }^{7}$ Antoni Mączak, Peregrynacje, wojaże, turystyka, Warszawa 1984, p. 173; B. STruck, op.cit., pp. 164-172.

${ }^{8}$ Piotr Ugniewski, Francuzi w Polsce $w$ drugiej połowie XVIII wieku (http://www.wilanow-palac.pl/francuzi_w_polsce_w_drugiej_polowie_xviii_wieku.html; access: 30 V 2014).

${ }^{9}$ A.-M. Fortiade de Piles, L. de Boisgélin de Kerdu, op.cit., vol. 1, p. I. 
situation, the Frenchmen exposed themselves to ridicule, fell into trouble and were even swindled ${ }^{10}$. The information presented in Voyage de deux Françai concerned the functioning of transport stations, the condition of roads, water transport, parking sites, accommodation, charges for luggage, means of transport (by horse, coach or ship) in the countries visited by Louis de Boisgélin de Kerdu and Alphonse Fortia de Piles. The aim of the publication was to limit or eliminate the embarrassing situations. In this way, the target audience of the travel account was closely defined ${ }^{11}$. In the introduction Alphonse Fortia de Piles expressed his hope that future travellers should avoid the various obstacles and inconveniences described in Voyage de deux Français $^{12}$. He also stressed that both Louis de Boisgélin de Kerdu and Alphonse Fortia de Piles made an effort for the information to be as precise and detailed as possible in order not to misinform the readers. He also emphasised that they had actually witnessed the places and things described by them, which meant that the opinions expressed did in fact result from what they had observed and could differ from what had been presented by other travellers; yet, they had done their best to be impartial and honest ${ }^{13}$. The content of the account was embellished with information taken from other works and readings about the countries visited by Louis de Boisgélin de Kerdu and Alphonse Fortia de Piles. On the other hand, it was marked by an individual attitude and private perception of the places visited, reflected in the opinions and conclusions resulting from their own experiences ${ }^{14}$.

Moreover, in Voyage de deux Français there was a description of towns visited, buildings of public utility such as hospitals, orphanages, medical and military schools. The emigrants paid much attention to the seats of monarchs depicting castles, palace, library collections and collections of minerals along with natural history exhibits. They were also interested in other aspects which influenced the significance of a given country; thus, in their accounts they did not omit such issues as economy, the condition of military forces (including the navy).

The account started with leaving Strasbourg and crossing the bridge on the Rhine river in order to get to Kehl situated on the opposite bank, in the territory of Baden. The crossing had both a real and symbolic dimension. It divided the emigrants from the revolution, created a distance in relation to direct revolutionary events. It also marked the geographical-cultural distance as the travellers found themselves roaming beyond the Romance area and entering a culturally different territory having left Strasbourg. They moved to areas differing in customs, habits, cultural and regional aspects. These factors meant that crossing the borders was felt individually and took on a dimension of personal experience ${ }^{15}$.

${ }^{10}$ Ibid., pp. V-VI.

${ }^{11}$ Antoni Mączak, Odkrywanie Europy. Podróże w czasach renesansu i baroku, Gdańsk 1998, pp. 29, 87-89; B. STRUCK, op.cit., pp. 111-114.

${ }^{12}$ A.-M. Fortiade de Piles, L. De Boisgélin de Kerdu, op.cit., vol. 1, p. IV.

${ }^{13}$ Ibid., p. VI.

${ }^{14}$ A. MĄCZAK, Odkrywanie, pp. 5-6; B. STRUCK, op.cit., pp. 21, 93.

${ }^{15}$ A. MącZaK, Odkrywanie, p. 166; B. STRUcK, op.cit., pp. 186-200; Monika Milewska, Ocet i łzy. 
Bridges played an important role in moving all over Europe - they provided the opportunity to travel to various places. Louis de Boisgélin de Kerdu and Alphonse Fortia de Piles crossed bridges quite often when they found themselves on the Danuba or the Elbe rivers; they started their journey by crossing the Rhine. In this case, they noticed that Kehl was a convenient point for smuggling forbidden books which had not been allowed for official print.

The towns which they visited in the original stage of their journey were Rastatt and Karlsruhe, next Stuttgart and Ulm. The road seemed to them to be straight and wide, with numerous villages along the way; the territory was populated and its inhabitants lived in prosperity. In the last part of the journey leading to Ulm the scenery changed; the road led through a hilly area. To get to Ulm it was necessary to cross the bridge in Plonchingen ${ }^{16}$. After they left Ulm, they went to Augsburg; they described the road there as nice, but not very fast ${ }^{17}$. From Augsburg they went to Munich entering the area of Bavaria. This was connected with the necessity to undergo a luggage check on the Lech river, where they crossed a bridge again. While in Munich, they saw the Nymphenburg Palace. Next, they went to Landshut and Regensburg; the road leading to the cities seemed beautiful to them. From Regensburg it was possible to get to Vienna by ship or coach; however, both means of transport were quite costly. A journey by ship cost 100-150 florins, whilst a journey by coach was $40-50$ florins. From Regensburg the emigrants headed for Vienna through Straubing and Deggendorf, where they crossed another bridge. Its characteristic feature was that loaded caravans or carts could cross it; this kind of bridge was quite popular on the Danube ${ }^{18}$. In this way, having entered the territory of Austria, they reached Passau. During this part of the journey, the Danube was quite wide, but the scenery soon changed and pine forests started to appear and prevailed on the way to Passau ${ }^{19}$. Passing such places as Linz, Ips, Melk, Stein, the emigrants reached Vienna, the subsequent point on the itinerary being Prague. They did not have good memories of the section of the road leading from Vienna to Prague. They stressed that only some of the 21 transport stations were maintained, while the others had been abandoned. The journey was tiresome; it took about 60 hours (stopovers included), but the country looked nice to them. Passing Kolín, the emigrants recollected a battle in 1757 during the Seven Years' War between the Prussian and Austrian army ${ }^{20}$. They disapproved of the journey from Prague to Dresden, expressing negative comments about the condition of roads as well as the method and means of transport. They complained about the inferior condition of the roads and the time-consuming journey, which had taken them as many as 29 hours with a handful of stopovers. The reason for their dissatisfaction

Terror Wielkiej Rewolucji Francuskiej jako doświadczenie traumatyczne, Gdańsk 2002, pp. 219-220.

${ }^{16}$ A.-M. Fortiade de Piles, L. de Boisgélin de Kerdu, op.cit., vol. 1, p. 7.

${ }^{17}$ Ibid., p. 8.

${ }^{18}$ Ibid., p. 25.

${ }^{19}$ Ibid., pp. 17-18, 24.

${ }^{20}$ Ibid., pp. 27-29. 
was also the small number of horses for exchange in transport stations; they were not suitable for travel, particularly at night. In Petersvald was the last customs control point before entering Saxony.

Louis de Boisgélin de Kerdu and Alphonse Fortia de Piles declared that the bad condition of roads and the obstacles in moving both ways resulted from the unfavourable policy led between Saxony and Austria. It did not facilitate the construction of new roads, communication routes and trade tracks, which hindered the exchange of goods and services as well as the flow of people. They also remembered other battles from the Seven Years' War: the battle of Lovosice in 1756 between the Prussian and Austrian armies and the battle of Pirna ${ }^{21}$.

On their way they did not omit Freiberg, a journey which took then 6 hours, and the stronghold of Koenigstein near Dresden. It was possible to get to the fortress in approximately 4 hours. They also announced that for two écus (crowns) it was possible to hire a horse. They had the opportunity to see the palace in Pillnitz and the well known manufacture of porcelain in Meissen (the journey took them three and a half hours). The next site on their itinerary was Leipzig. The road from Meissen to Leipzig was most inconvenient. The journey to Potsdam was equally tiring - it took them 31 hours ${ }^{22}$. The transport station in Treuenbrietzen marked a change in territory for, having passed through it, the travellers entered the Kingdom of Prussia. They advised other travellers to mention their name in Prussia at every occasion. Potsdam was the first Prussian town they visited, the next one being Berlin which, at that time, had over 170000 inhabitants. At this stage the road led through fields. Louis de Boisgélin de Kerdu and Alphonse Fortia de Piles stated with irony that although the distance between Paris to Versailles was comparable, it was hard to say that the two roads were also similar in quality. The road connecting Potsdam with Berlin was constructed soon after their visit in the years 1791-1793; they were witnesses of the beginnings of the works. The travellers emphasized that one had to pay a royal fee both when entering and leaving Berlin. They also advised arriving in Berlin during the day to be able to arrange all the customs formalities. Failing to fulfill such formalities could cause difficulties unless one encountered an official of a lower rank who would escort a traveller to an inn ${ }^{23}$. From Berlin they went to Rheinsberg. On their way to Hamburg they expressed their dissatisfaction with the sandy and uncomfortable roads, stopover points and the bad service at inns. Before they reached Hamburg, they recommended visiting Ludwigslust and the seat of the prince of Mecklenburg-Schwerin. They noted that from Lenzen it was obligatory to pay for a horse and there was an additional charge of a Lübeck mark at each stopover point; they also pointed out that the gates might be closed in every town. In Hamburg the city gates were closed at strictly defined

\footnotetext{
${ }^{21}$ Ibid., pp. 37-38.

${ }^{22}$ Ibid., pp. 105-109.

${ }^{23}$ Ibid., pp. 122-123.
} 
hours ${ }^{24}$. Having reached the Eider river and having passed the border between Prussia and Denmark, the travellers crossed the Duchy of Schleswig-Holstein, which at that time belonged to Denmark. From Jutland they went to the island of Funen, where they saw Assens, Odense and Nyborg. Next, they went by sea to Zealand, where they visited Korsør, Copenhaguen and Helsingør, situated at the Øresund strait linking Denmark with Scania, and the Baltic Sea with The North Sea. The travellers provided the reader with detailed information concerning the fees they had to pay for moving from one Danish island to another. In Arø, where there was a transport station, it cost 9 Lübeck marks to board a carriage, and it took them 7 hours to cross the distance of 2 miles. In Assens, the emigrants had to pay 5 shillings for embarking, one mark for each horse and a carrier. They reached Odense, where the charge was 4 shillings, and next to Nyborg, a small town, where they had to pay from 0,25 to 1 mark for a horse. They reached the strait of the Great Belt where they had to show their passports and pay a fee of 8 shillings; to board cost 7 riksdalers. They covered a distance of about 4 miles in two and a half hours. In half a hour they embarked in Korsør, where they had to pay 2 marks each and 4 marks for the carriage. The system of travelling by land stipulated that the coachman had to own and show a bill with the departure hour; he had to keep the itinerary. What is more, the travellers could evaluate the service - three negative comments entailed a penalty. The coach stopped very rarely, and sped up whenever possible. The emigrants wondered why such a system functioned only in the distance from Hamburg to Funen and whether it was only a Danish practice ${ }^{25}$. After they arrived in Zealand, they stopped in Korsør, where the customs officers turned out to be very meticulous, which the travellers recorded in their accounts ${ }^{26}$. The distance to Copenhagen amounted to 14 miles. On the way to Copenhagen they visited Roskilde and the cathedral with the tombs of the kings Christian III and Frederick II in the Chapel of the Three Kings. The villages they passed on the way did not indicate that the capital city was near or that the country and its people were wealthy. They stressed that in Zealand they had to pay a lot of money for horses: 15 shillings from Easter to the Day of St. Michael and 17 shillings from the Day of St. Michael to Easter; additionally, it was obligatory to pay 2,5 shillings for each mile.

Passing various areas, towns, villages, seats of monarchs, princes, electors, they described the places, their architecture, the number of inhabitants and specific features. The French emigrants saw most of the castles and palaces situated on their way. Being in Rastatt they wrote that the palace was worth seeing from outside, since inside there was nothing interesting. What is more, they wrote that the room where the agreement of 1714 between Austria and France terminating the Spanish succession war was signed, was one of the poorest palace rooms. According to

\footnotetext{
${ }^{24}$ Ibid., pp. 141-142. Comp. A. MącZAK, Odkrywanie, pp. 130-132.

${ }^{25}$ A.-M. Fortiade de Piles, L. De Boisgélin de Kerdu, op.cit., vol. 1, pp. 210-215.

${ }^{26}$ A. MĄCZAK, Odkrywanie, p. 166.
} 
them, it was worth climbing the stairs to admire the beautiful view. The palace in Karlsruhe and the town itself impressed them. The town, built in the middle of the forest, featured a highly regular layout and housing; it was surrounded by alleys leading up to the castles of Baden's monarchs and marking the streets. In Voyage de deux Français the external appearance of the castle was depicted. However, what was absolutely awe-inspiring was the marvellous and colourful view from the top of the castle - "vue superbe et très pittoresque, d'un côté la ville et les environs: de l'autre un fôret on ne voit pas la fin" ${ }^{\prime 2}$. The palace in Stuttgart seemed interesting to the travellers owing to the beautiful arcades and the room on the first floor decorated with marbles in different colours. It was not inhabited, as the duke of Württemberg spent more time in his new seat located three miles from the capital. The rulers of Württemberg were famous for being extravagant, spending money on building further palaces, paying for mistresses or organising hunting expeditions. The remark about the new seat referred to the palace erected by Charles Eugene who, in order to acquire funds for his expenses, sold his subjects to foreign armies. Visiting the seat of the duke of Württemberg they admired the rich and valuable library. They estimated that the duke of Württemberg, passionate about old books: "le prince a la fureur des livres anciens"28, collected 100000 copies. They paid special attention to the collection of the Bible in various languages and editions; the collection included 9000 volumes and, according to the travellers, 3000 volumes were missing to achieve a complete collection. What they found the most interesting was the New Testament in Russian consisting of five volumes printed upon the permission of the tsar Peter the Great. It is worth mentioning that the collection included also the Polish edition of the Bible of 1563 from the collections of the Radziwiłłs ${ }^{29}$.

Passing through Ulm and Augsburg they described the Gothic and Jesuit churches. They expressed their opinion that Ulm - famous for trade - had passed its prime; Augsburg did not impress them, either. What drew their attentions in particular in Ulm was shipping and rafting down the Danube along with the significance of the river route for the development of trade and towns ${ }^{30}$. The house of the Liberts and the hydraulic machine grabbed their attention ${ }^{31}$.

Entering Bavaria they noticed several characteristic features of the territory. One of them was the extraordinary religiousness of the Bavarians, the evidence of which were numerous sculptures of saints. A huge number of religious signs and symbols reflected the situation in Bavaria. It should be highlighted that for this duchy, the Church and the Catholic faith were tools used to strengthen their power. The next characteristic feature of the region was the huge popularity of

\footnotetext{
${ }^{27}$ A.-M. Fortiade de Piles, L. De Boisgélin de Kerdu, op.cit., vol. 1, p. 2.

${ }^{28}$ Ibid., p. 5.

${ }^{29}$ Ibid., pp. 5-6.

${ }^{30}$ Ibid., pp. $7-8$.

${ }^{31}$ Ibid., p. 10.
} 
the hops for producing beer. The travellers noticed that in Bavaria the level of science was quite advanced, but not as advanced as in leading European centres. Moreover, Bavaria seemed to be quite densely populated, despite the fact that its population had suffered losses during the succession war. During the visit of Louis de Boisgélin de Kerdu and Alphonse Fortia de Piles it was an agricultural area, in which economy and industry was not developed. The travellers concluded that the low level of economic development resulted from a lack of interest on the part of the Bavarians, their indifference, lack of industrial potential and dynamics; the only operating branch of industry was weaving. Hospitals, though quite rich, were badly administered and not well provided for ${ }^{32}$. The travellers' judgement concerning Bavaria referred to the condition of the country after its collapse, which was the consequence of the policy and the lifestyle of its rulers. The first major centre visited by them was Munich, whose population they estimated at 36000 inhabitants. The court garden, Hofgarten, seemed boring and monotonous to them. They paid attention to the activity of Benjamin Thompson, who created another garden - the Englisser Garten - along with the botanic garden where various plants, sometimes difficult to maintain in the Central European climate, were cultivated. An extraordinary element of the garden was a pavilion where an echo could be sounded in an impressive manner. According to the beliefs of the authors of Voyage de deux Français this could have been caused by a close wall situated near the pavilion. The residence of the Bavarian elector with its marble stairs and pillars made an opposite impression on the travellers. What they found extraordinary was the imperial room where concerts were given, the lounge (whose ceiling was decorated with a painting presenting a carriage drawn by four white horses, which gave the name "chevaux blancs") and a richly decorated chapel. In the royal gallery one could admire the collection of paintings, the collection of miniatures including the statuette of Orpheus by Jacques Koenig, estimated at 30000 florins. The whole painting collection included 600 canvasses in seven rooms. The emigrants admired the treasury with jewels and precious stones such as rubies, pearls, diamonds along with statues made of silver and gold-plated bronze. They also depicted book collections including a few editions of the Bible, works of Virgil, several volumes of the missal and an Egyptian papyrus ${ }^{33}$. In the palace of Nymphenburg they emphasised the great number of pavilions creating the palace establishment, the dining room with a terrace, many rooms in the Chinese style, from which one could admire beautiful sights. They stressed that all the buildings and pavilions were richly decorated. They enjoyed the garden full of greenery with water containers, which created interesting perspectives for people walking there; at the same time they were not especially fascinated with the sculptures. They also listed the buildings of the garden: Pagodenbourg in the Chinese style, Madenbourg, l'Hermitage and Amelianbourg. The last building seemed to them the most interesting owing to its

\footnotetext{
${ }^{32}$ Ibid., pp. 11-12.

${ }^{33}$ Ibid., pp. 15-18.
} 
exquisite rococo richly-decorated style and the rotunda shape with silver-plated mantelpieces.

Regensburg, the town which used to flourish and develop thanks to trade, now made a sad and gloomy impression on them: "Elle est noire et triste". In those times the town had passed its prime. Neither the eight-hundred-foot long bridge on the Danube nor the nearby mills saved Regensburg from collapsing. The room in the town hall where meetings of the town council were held was very simple which, according to the travellers, was evidence of the burghers' parsimony. From Regensburg they headed for Vienna; however, in this volume they did not describe the capital of the Habsburg empire since they devoted to it another part of their account, where they included their remarks concerning the city. They started the description of the Austrian Empire with Passau and the bishops' palaces there; yet, the buildings did not seem interesting enough and they did not devote much space to them. Although Passau was the town with the bishopric, the policy of Joseph II, who continued the church policy of his mother, changed the situation of the Roman Catholic Church in Austria. The effect of this was the restriction of the power and jurisdiction of the bishop in Passau. The town's church was small but sufficiently decorated. On the pulpit the travellers noticed an hourglass used to measure the time of preaching. They wrote that the custom of placing an hourglass on the pulpit was quite widespread in the German territories. They described Linz warning future travellers of how dangerous it was to cross Saint-Nicolas. They advised crossing it very quickly to minimise the risk. The place inspired fear owing to the considerable number of religious symbols and statuettes of saints, which were to guard passers-by. On their way they also passed the abbey of St. Benedictine in Melk and the town of Stein ${ }^{34}$. Next, from Vienna they went to Prague through Znojmo [German: Znaim], Jihlava [German: Iglau] and Kolín. Among the places they visited in Prague they described the castle, the church of St. John Nepomucene, the famous church of the Blessed Virgin Mary with the tomb of Tycho Brahe. They could not have omitted in their account one of the most famous bridges in Prague - the Charles Bridge. They estimated its length at more or less 1460 feet, which corresponds with its actual length. They remarked that the sculptures on the bridge were not very pretty; the only distinguishing statuette was the one of St. John Nepomucene. As usual, Louis de Boisgélin de Kerdu and Alphonse Fortia de Piles did not fail to describe the library the collection of which included 130000 books and 8000 manuscripts. This magnificent collection included Latin gospels from the $8^{\text {th }}$ century, prayer books, logarithmic tables by Tycho Brahe, the university's annals and the editions of the Bible of the $15^{\text {th }}$ century, including the edition by Johann Gutenberg. Translations of the Holy Scriptures written in Glagolitic were extremely rare and precious from the end of the $12^{\text {th }}$ century and the beginning of the $13^{\text {th }}$ century; works of ancient writers and books concerning Natural History. The library was equipped with an open room for readers, who could use the books

${ }^{34}$ Ibid., pp. 20-28. 
in the mornings. According to the emigrants, the creation of the library collection cost 6000 florins $^{35}$.

Despite the fact that they complained about the journey from Prague to Dresden, they considered Dresden to be quite an interesting town with many places worth visiting such as a 1130 footbridge. One of the attractions they mentioned were the gardens of the Dutch palace and terraces surrounding the palace of Heinrich von Brühl. They recommended taking a walk down a colourful and picturesque path leading along the river Elbe; they also wrote about baths open to the public, where concerts and performances took place. Sacral buildings such as the royal chapel of the Holy Trinity and the Church of the Blessed Virgin Mary drew their attention. The former was no more than fifty years old; its construction was not complete until the first half of the $18^{\text {th }}$ century, while the Church of the Blessed Virgin Mary had a very appealing appearance. It was constructed on foundations in a rotunda shape which then rose up to the higher storeys. One could get to those storeys by walking under the arcades. They devoted a few words to the orchestra which played during Sunday mass; they highlighted the talent and skills of the famous cellist Jean Balthasar Tricklir. They had mixed feelings while writing about Italian opera and theatre - not all opera performances and plays were worth seeing. They mentioned a famous fair dating back to the $15^{\text {th }}$ century, which took place in Dresden at that time. Still, they did not regard it as especially interesting. They were astonished that such a famous event lasted only two days.

The garden of the Saxon elector situated beyond the boundaries of the city caught the travellers' attention. There were many birds in it, particularly pheasants. However, as it was October 1790, it was hard for them to notice all the virtues of the garden. The chilly autumn weather meant that they did not manage to see the whole garden. In the elector's palace they noticed the richly decorated representative rooms and the rich collection of paintings. They regarded it as the biggest and the most significant in Europe; they wrote that only the collection of the House of Borgia in Rome and the collection in Saint Petersburg could equal it. Yet, the latter collection was significantly smaller the Saxon one. It included canvasses by painters belonging to the Flemish schools of painting and Italian artists. The collection was exhibited in a few galleries, but there were so many paintings that some of them were lying scattered on the floor. Louis de Boisgélin de Kerdu and Alphonse Fortia de Piles estimated that eight hours were required to see the whole collection at one time; yet, they indicated that it was advisable to return a few times to discover the full wealth of the collection. A complete and detailed list of the canvasses and their authors was provided in the account; they also announced that a guided tour of the gallery cost 1 ducat. The library of the Saxon ruler constituted a rich collection of historical books concerning the history of European countries, works of Greek and Latin writers, the psalter of 1457, the copy of the work concerning military issues donated by the Hungarian king Matthias Corvinus, letters of St. Paul from the $11^{\text {th }}$

\footnotetext{
${ }^{35}$ Ibid., pp. 33-36.
} 
century, Homer's works of 1488 published in Florence and a collection of Bibles (in German, Latin, French, Italian, etc.). The rarity amongst the collection was a Mexican manuscript. As the travellers wrote, it included fragments of history and the calendar referring to the civilisation of the Incas, which was not a precise statement. Most probably, Louis de Boisgélin de Kerdu and Alphonse Fortia de Piles referred to one of the few preserved manuscripts - original texts of the Maya people, which has survived up to now and is known as the Dresden Code. It is an extraordinary and unusual source concerning the history of the Maya people. It includes astronomical and astrological calculations along with other information concerning their rites, the system of measuring time and the elements of the calendar. They did not forget about the unusual collection of porcelain with very rare specimens of old Saxon porcelain, items of Japanese porcelain, Chinese porcelain, Italian faience, and even three vases with the coat of arms of the Polish king. The collection also included the figure of August III on a horse. In the treasury there were items made of ivory, jewels made of amber and other stones such as amethysts, topazes, agates along with tableware including cups that belonged to the tsar Peter I. Moreover, the elector's collections included many various items such as clothes from other epochs - some of them in a poor condition. For one ducat it was possible to see some exhibits of natural history such as lime, marbles from various countries, fossils with the impression of fauna and flora, alabaster from Thuringia, amethysts, agates, jaspers, basalt along with the exhibits found in Wieliczka "dans la Pologne Autrichienne". They also saw one private collection of minerals ${ }^{36}$.

The ambiance at the Saxon court made a bad impression on the emigrants. The court, which in the past had been full of glamour and life, had now become a gloomy and depressing place. The atmosphere at the court was directly connected with the personality of the ruler Frederick August III (the Saxon elector in the years 1763-1806, the Saxon king in the years 1806-1827, the duke of Warsaw in the years 1807-1815) and the personality of his brothers - particularly his religious brother - Anton. Frederick August III had conservative views, which he expressed in his predilection for baroque clothes and the court etiquette. He reduced the number of parties and significantly restricted theatrical life; the revival of the theatre took place thanks to the initiative of his wife. Owing to the disposition of the closest members of his family, an atmosphere of piety prevailed at the court. The emigrants noticed the changes which had taken place in the style of the court life: "rien de plus triste que les bals de la cour, et de plus plaisant en même temps pour létiquette qui y est observée" ${ }^{37}$. They even told an anecdote that the duchess of Courland did not go to balls or performances due to a mental breakdown; they referred to the religiousness and piety at the court as devotion. They also expressed their opinion about the women saying that they were not as nice and kind as those in Vienna. They recapitulated their observations concerning the atmosphere at

\footnotetext{
${ }^{36}$ Ibid., pp. $48-81$.

${ }^{37}$ Ibid., p. 47.
} 
the Saxon court as follows: "la libertinage est poussée fort loin à Dresde" 38 . They observed the relations between the Saxon elector and his brothers and other members of the court. They stressed the manner in which the elector treated his brothers, officials, courtiers, officers and soldiers. Writing about the income of the Saxon elector's brothers and ministers, the travellers stated they were quite modest. The remarks referred to the fact that Frederick August III marginalised his brothers' influence on decisions and political issues; they were deprived of their political obligations and restricted to representative functions only. In contacts with representatives of the state administration, court groups there ruled according to a hierarchy depending on the titles, ranks and offices held. In relation to his subjects, the elector was quite detached, and told the members of his government and court to do the same. Here, Louis de Boisgélin de Kerdu and Alphonse Fortia de Piles made one of the very few remarks concerning the revolution in their country. They observed that the ruler of Saxony had not talked with the French since 1790. Describing the Saxon ruler, they wrote that the elector knew foreign languages, collected minerals, loved music, was a good soldier, and his favourite pastime was hunting. Apart from his predilection for music, he was not interested in the development of art while his hunting caused losses for the inhabitants of the countryside. While hunting, the inhabitants of the village were obliged to prepare it and take part in it - for example, as beaters to please the elector. When game appeared, they were not allowed to touch it under the threat of being sent to the galleys, even if the animal entered and destroyed their field. Writing about the fate of peasants, the migrants added at the end: "il ne faut pas que ce même paysan garde pendant l'hiver", wondering whether in winter they would be protected by their ruler. The ambiance felt at the court affected the inhabitants of Dresden. The evidence for this was the fact that after 10 o'clock p.m. it was rare to find anyone in the street; the lights in the majority of houses were switched off. Those who owned estates stayed there; the privileged visited each other never going beyond their social class. In such a situation, it was difficult for a foreigner to establish social contacts ${ }^{39}$.

Before they arrived in Freiberg, they had described the factory of porcelain situated 4 miles of Dresden, where glass objects were made with the help of machines $^{40}$. Freiberg was mainly associated with the development of mining. They referred to the Mining Academy where mining, mineralogy and mathematics were studied; one of the best known professors was Abraham Gottlob Werner, who owned a very interesting collection of various minerals. Teaching was based on the discoveries of French scientists - Antoine Lavoiser, Antoine Françoise Fourcroy, Claude Louisa Berthollet - yet, the French classification system was not used. The whole course in the school cost 500 écus, but it was also possible to buy one lesson for 16 groschen. The travellers related that in the area of 5000 miles there were

\footnotetext{
${ }^{38}$ Ibid., p. 48.

${ }^{39}$ Ibid., pp. 44-47.

${ }^{40}$ Ibid., p. 52.
} 
250 mines of silver, zinc, lead, which were mostly private properties of burghers, Jews or representatives of noblemen. Louis de Boisgélin de Kerdu and Alphonse de Fortia de Piles had an opportunity to see the elector's mines, where they could travel in a hired coach for 3 florins. However, at the moment of their visit, it was impossible to enter the mine as it was flooded. To exit the mine one had to pay 8 groschen for being transported in a special machine. They depicted a gloomy image of the poverty which the miners and their families had to cope with. The miners worked 5 days a week for 20-27 groschen a week; young people for 8-12 groschen and children for 5-6 groschen a week. According to the emigrants, they were badly paid, lived in very modest conditions, but almost all of them had wives and children. The authors of Voyage de deux Français described the whole process of processing and smelting iron ore, which they had not seen in other European countries and which astounded them. Historically, they recollected the battle of Henry of Prussia of $1762^{41}$.

They made for Koenigstein, a famous fortress, the journey to which took them 4 hours by horse hired for 2 écus. The barracks could be visited having obtained a permission in Dresden, which cost one ducat. To see the whole of it one had to pay 6 or 7 ducats; still, not everything was worth seeing. Louis de Boisgélin de Kerdu and Alphonse Fortia de Piles recommended seeing a well with a shadoof and casemates whose admission fee cost 6 groschen. It turned out that the casemates were quite narrow, but could hold about 2000 people. The attraction of the tower was the well, which could be seen for one florin paid to the head of the place and 8 groschen to the person turning the wheel. As the casemates abounded in corridors and were quite extensive in space, one could hire a guide for 2 florins, a drummer for 6 groschen and 6-8 groschen had to be paid to the guard at the exit. In times of peace, the fortress was not heavily manned; the number of soldiers rose during a war; the fortress was very well equipped and armed. It was hard to conquer thanks to its location on the rock and being surrounded on one side by the hill of Lillinstein, where in 1756 there was a battle, and on the other side by the Kerl mountains. Koenigstein was a significant military object in Saxony, which also played the role of a treasury.

The emigrants were not particularly enchanted by the palace in Pillnitz, which had been built for the mistresses of Augustus II the Strong. The only thing they highlighted was the fact that the plants, trees and bushes were not transported to glasshouses for winter, but glasshouses were arranged around them during times of vegetation. They made a reference to the conference and declaration of Pillnitz of 1791, of which some Frenchmen had high hopes and expectations, which were eventually not fulfilled. Leipzig did not seem very interesting to them; they wrote that the town was worth visiting only during fairs. The characteristic feature of the town was the great number of handicapped people seen in the streets. What drew their attention were the very favourable prices of furs and skins which, as they

${ }^{41}$ Ibid., pp. 89-100. 
believed, could only be found in Leipzig ${ }^{42}$. The town played a major role as it was situated at the crossing of trade routes. The fairs mentioned above and the book trade influenced the development of the city, which was additionally strengthened by fixing monetary and financial issues with Brandenburg.

Saxony, despite all the aforementioned aspects, remained an agricultural country. The foundation for the economy was agricultural produce: wheat, rye, buckwheat, peas, potatoes, barley, oats - all produced in quantities which exceeded the needs of the whole country. However, their observations concerning the industry of Saxony demonstrated that even in this field a significant development had taken place thanks to refugees from Bohemia and Austria along with the Huguenots from France. Owing to their mobility and resourcefulness, branches of industry such as mining, clothing, the manufacture of luxurious products such as velvet and silk along with the production of porcelain developed. Saxony, which had lost its significance in the German Reich, developed internally. The weakness of the country was the administrative division and the political system. The emigrants stressed the excessive administration and a distinct political system which differed from those in other countries ${ }^{43}$.

Before they reached Potsdam they had visited Wittemberg, famous for the presence of Martin Luther and Philipp Melanchton, whose tombs were to be found in the church ${ }^{44}$. According to the travellers, Potsdam, whose housing was quite regular, was badly cobbled. The municipal palace was not worth seeing and paying several écus as an admission fee. The New Palace of Sanssouci, constructed after the Seven Years' War, constituted a very attractive place to see. In the old palace of Sanssouci they recommended seeing the dining room with its magnificent view which, as the emigrants noticed, was quite rare in such rooms. Another interesting place was a small audience room, while the bedroom was quite simple. In the palace an appealing collection of paintings was to be found. In the garden there were a few pavilions and greenhouses along with the tombs of the dogs of Frederick the Great ${ }^{45}$.

Having arrived in Berlin, they paid attention to the sight from the side of Unter den Linden to the Brandeburg Gate. After visiting the castle, they described its library collections ${ }^{46}$. The organisation of the library astonished them. They noticed that books in the royal library were arranged without any order. When they tried to ask a librarian about a few books, it turned out to be impossible to get them. What is more, they were taken for madmen since they expected to receive the impossible: "il (le bibliothécaire) nous a pris sans doute pour des fous ou imbeciles" 47. The ignorance of the librarian resulted from his lack of orientation in the library resources and the mess in the library. Other buildings they described included the

\footnotetext{
${ }^{42}$ Ibid., pp. 89-108.

${ }^{43}$ Ibid., pp. 38-43.

${ }^{44}$ Ibid., p. 109.

${ }^{45}$ Ibid., pp. 113-122.

${ }^{46}$ Ibid., pp. 123-125.

${ }^{47}$ Ibid., p. 130.
} 
Berlin opera, the horse stables which reminded them of a ballroom. As they wrote, military manoeuvres were conducted there to accustom the horses to the noises of the army. What caught their attention was the fact that the handicapped received far less help from the state than orphans. They attributed this to the tradition, policy and the character of Prussia as a military country. In this context, it was much more profitable for the state to keep and maintain a well-trained army rather than soldiers who could no longer take part in battles: "cela vient de ce que dans pays où l'on sait aussi bien le prix d'un homme on pense bien beaucoup plus aux soldats futurs quaux soldats passés"48. They expressed their admiration for Frederick the Great and his reforms, which led to the strengthening of Prussia and increasing the power of the state.

The travellers also mentioned that there were quite a few Frenchmen in Berlin. They were either expatriates and their descendants from the times of revoking the Edict of Nantes or Frenchmen who arrived in Berlin during the times of the French Revolution. Louis de Boisgélin de Kerdu and Alphonse Fortia de Piles thought very highly of Henry of Prussia, who exhibited a friendly attitude towards the French. The authors of Voyage de deux Français advised future travellers wishing to visit its seat in Rheinsberg that they should make an appointment. Those who had an opportunity to meet Henry of Prussia would not regret it as they would meet him in a small group of people. After the conversation with Henry of Prussia the travellers concluded that he supported the revolution in France. However, according to them, the prince's support resulted more from his hatred towards royal despotism rather than the approval of the new (yet to be established) constitution. They described the prince, who, despite being considered to be an opponent of war, showed great courage and bravery and invariably cared for the lives of his soldiers.

In the park in Rheinsberg there were many places to walk; along with other buildings a pyramid was erected there, which became a tomb for Henry of Prussia. The travellers did not think highly of the theatre where mainly French plays were staged. They considered the level of performances to be unsatisfactory; they also ridiculed the decorations and costumes. Inns were not very comfortable, and they advised looking for accommodation in the prince's place for only one ducat. This was possible if the stay did not last longer than 3-4 days. They once again visited the porcelain factory; however, they were not allowed to see the production technology - they could only tour the warehouses. They also provided descriptions of other manufactures and factories ${ }^{49}$.

To their way of thinking, Hamburg was a neglected and damp city, with narrow houses made of brick and wood designed with triangle roofs; the streets were badly paved, if lit with street lights. The suburbs were not very safe - there had been cases of young men being kidnapped and taken on board ships. According to the travellers, the city had 100000 inhabitants including 10000 Jews. Owing to its geographi-

\footnotetext{
${ }^{48}$ Ibid., p. 134.

${ }^{49}$ Ibid., pp. 131-141.
} 
cal situation, it was endangered with frequent floods such as the one in 1771. At the end of November 1790, when the travellers were staying in Hamburg, the level of the Elbe had risen dangerously. The main boardwalk ran along the river Alster, from which one could admire the sights. They also mentioned the theatre and opera, but pointed out how hard it was to get near the opera in a vehicle. The narrow streets were packed with vehicles. They remarked that in Hamburg it was customary to give one mark to porters just like in Holland or among the Frenchmen staying in Berlin. What distinguished Hamburg from the hitherto visited cities was its commercial character, which was reflected in the large number of warehouses, storage facilities, a stock exchange, where there were always many people doing their business and dealing with trade. Louis de Boisgélin de Kerdu and Alphonse Fortia de Piles estimated that there were usually 2000 of them, many of whom were Jews.

The travellers remarked that coffee was incredibly popular and some inhabitants of Hamburg earned their living as coffee traders. Another equally popular and commonly consumed product was beef imported from Norway, DenmarkJutland or Holstein. They listed three types of beef: salted beef for 3 sous, raw beef for 6 sous and smoked beef for 12 sous. Apart from commerce, in Hamburg one could come across exchange points and banks dealing in different currencies. They highlighted the low standard of art and literature - the only famous person was the poet Friedrich Gottlieb Klopstock. As they remarked, it was easier to read his works than to visit him. Although they made attempts to see him, they did not succeed. The travellers recommended seeing places such as Altona, Flottbek with some interesting houses belonging to burghers ${ }^{50}$.

To get from Hamburg to Copenhagen, one had to cross the Kiel Canal, which was quite expensive and could be fairly dangerous if the weather conditions were bad. In Schleswig they saw the mausoleum of Frederick; they described Flensburg as a Danish trading town, which could not be compared with Hamburg despite the fact that it had a beautiful seaside road ${ }^{51}$. Having crossed the island of Funen and reached Zealand through Koroser they arrived in Copenhagen. They depicted the city as reasonably small and pleasant with paved, narrow and well lit streets and houses. The emigrants recounted that in Copenhagen there were about 4000 houses, some of which were inhabited by soldiers and seamen. What caught their eye was Goth street and the square of Frederick V with his monument by Jacques Saly and the surrounding streets leading, one of which ran to the church and the other to the harbour. In Protestant churches, the services were held in German and French. There was a small citadel in Copenhagen, which was a well fortified town. One could watch performances (such as opera or comedy) four times a week. In the castle of Christiansborg situated on the island, there was a collection of paintings by various artists. Moreover, one could see items such as stuffed animals, fossils, silver from Norwegian mines, pieces of gold, emeralds from Iceland, mum-

\footnotetext{
${ }^{50}$ Ibid., pp. $143-150$

${ }^{51}$ Ibid., p. 182.
} 
mies, elephant teeth, items made of ivory, amber, Arabic and Turkish products, statuettes of Egyptian and Etruscan gods, models of Indian temples, collections of Chinese porcelain, items of worship from the tribes from North Europe. The travellers estimated that the rooms in the castle such as the knight's hall and the royal apartments had modest decorations. On the other hand, the chapel, some ornaments of which were made in marble, was quite richly embellished. The library included 130000 books and 3000 manuscripts. Among them there were some religious books, the Danish chronicle of the $15^{\text {th }}$ century, manuscripts by a traveller Karsten Neibruh, the Danish Bible, the Icelandic Bible, a collection of works devoted to Spanish history and Icelandic history, the Danish psalter in four languages along with works by ancients authors. The emigrants also visited the castle of Rosenborg and the palace of Charlottenborg, where there was located the school of painting, architecture and sculpture. Apart from this the saw the botanical garden, the observatory and the university library with Icelandic runic manuscripts from the times of Valdemar I and the Hungarian and Danish translations of the Bible. Particularly interesting were the private collections such the specimens of natural history collected by Johan Theodor Holmskjold. Yet, Louis de Boisgélin de Kerdu and Alphonse Fortia de Piles maintained that art and literature did not develop in Denmark as well as in other countries owing to the Danish mentality and climate, which was not as severe as in Sweden, Russia or Norway, but still did not facilitate the development of art. The emigrants made associations here to popular climatic theories, which explained the temperament and specificity of the inhabitants of various regions. Referring to political questions, they mentioned that Denmark could play a significant role in European policy as a state ensuring balance. However, the Danish authorities and government advocated the policy of neutrality, which, according to the travellers, limited the political advance of Denmark ${ }^{52}$.

Writing about the Danish rulers they stated that King Christian VII did not have any responsibilities except signing edicts and orders. It was Frederic VI, referred to as a young prince, who fulfilled the monarch's duties. They claimed that Frederic VI's activities restricted the ambitions of some ministers, which meant that some people considered that Frederic VI supported absolutist tendencies. Nevertheless, according to Louis de Boisgélin de Kerdu and Alphonse Fortia de Piles, despite his young age, Frederic showed some knowledge of political issues and exhibited responsibility. They considered him to be prepared to rule the country. They also wrote that his sister Luisa Augusta was the embodiment of female grace and perfection ${ }^{53}$.

In relation to trade in the Danish state, the travellers highlighted extensive businesses in various parts of Europe and the world. The East India Company, established almost 200 before, organised trade from India and China. Another field of commercial influence were the colonial islands such as Saint-Croix. They traded in

\footnotetext{
${ }^{52}$ Ibid., p. 188.

${ }^{53}$ Ibid., pp. 213-255.
} 
sugar, cotton, coffee, rum and slaves. The trade with the African coast did not develop very well; it was focused mainly on the trade in slaves and arms. Commerce in the Baltic region looked similar; in the Mediterranean region it was even worse, which was caused by the great competition of goods from Spain and France. Denmark produced wool, but the basis of the Danish economy was fishing. Denmark possessed ships scattered from Greenland to Norway, Jutland and Zealand, in which wine, fruit, oysters, and coffee were imported and fish, grain and wood exported.

Louis de Boisgélin de Kerdu and Alphonse Fortia de Piles's travel and its description in the German states and Denmark generated several interesting conclusions.

The aim of the journey was to visit countries which, apart from Russia, were not frequent tourist destinations; they strayed from the beaten track in deciding to visit the countries of Northern Europe. Their decision was determined by the situation in which they found themselves. Leaving France, they became emigrants, whose lives were influenced by both the political situation in France and their personality. They did not decide to settle down in any of the courts they had visited; instead, they chose to head for lesser known areas. Their experience as emigrants shaped their curiosity and desire to get to know distinct territories. The chosen route to the "northern countries" reflected their originality and travelling style extending beyond the European classics ${ }^{54}$.

The aim of the trip was to become familiar with the places they were to visit. They also wanted to share the information about their manner and conditions of travelling. They described the quality of roads and the pace with which they moved from one place to another. They devoted a great deal of space to depicting dangerous places, which were hard to access and were situated in a severe and cold climate. They highlighted the bad condition of roads and slow transport in the countries of the German Reich; negative opinions about road conditions in the Reich also appeared in accounts by other travellers ${ }^{55}$. They described the functioning of the transport system, expressed their views about individual stations, where it was possible to change horses or wait for a carriage with a coachman. They were absolutely delighted with the Danish system, where the exchange of horses was not problematic. One did not have to wait a long time for a carriage since the ticket obliged the coach to leave at a specified time. It was also possible to write comments concerning the quality of service on the ticket. Nevertheless, they stressed that in Denmark the fare were very high and differed from place to place. They also frequently mentioned bridges. They did not think highly of the inns where they sojourned, complaining about the disgusting conditions, bad quality of service and accommodation $^{56}$.

\footnotetext{
${ }^{54}$ A. MąCZAK, Odkrywanie, p. 6.

${ }^{55}$ Ibid., pp. 77-78; B. STRUCK, op.cit., pp. 125-130.

${ }^{56}$ Comp. Antoni MĄczaK, Życie codzienne w podróżach po Europie w XVI i XVII wieku, Warszawa 1978, pp. 37-41.
} 
Another characteristic element of the account was the description of the landscape, villages, towns and estates. Their remarks were brief and sober - they related mainly to the dangers, hardships and obstacles in travelling. They did not fail to include remarks about the efficiency and usefulness of agricultural territories and the countryside, which was typical of travel accounts of the end of the $18^{\text {th }}$ century. Their comments concerning the beauty of nature reflected the appearance of a new way of describing nature, presented through the prism of its beauty and admiration ${ }^{57}$. Describing the German towns they highlighted that some of them had passed their prime, having flourished between the $15^{\text {th }}$ and $17^{\text {th }}$ century. This mainly concerned the Protestant trade cities, whose status and position during the time of the travellers' visit was not so significant.

The next feature of the account was that the Frenchmen emphasised the significance of French culture and science. Another curious thing is that they paid attention to plays, theatrical performances and operas, and frequently expressed their opinions about them. They also proved their knowledge of art by commenting on artists and their oeuvre. They presented remarks concerning painting and sculpture as well as the collections of the rulers and individuals, which again was evidence of their artistic knowledge. They visited libraries and archives, revealing their competence in this field too.

They infrequently referred to politics and the revolution taking place in their country. They mentioned the community of Frenchmen in Berlin, the Pillnitz declaration and the attitude of Henry of Prussia and the Saxon elector towards the French.

They included the information about the military capabilities of the territories visited, their medical conditions, the situation of orphans and the handicapped while also pointing out public buildings and institutions in those places.

Starting their journey by leaving Strasbourg and reaching the Great Belt, Louis de Boisgélin de Kerdu and Alphonse Fortia de Piles covered huge areas of land. Driven by curiosity, they managed to stray from the beaten track. Certainly, they belonged to the group of emigrants described as "ils nont pas leur temps".

Received $7^{\text {th }}$ July 2015

Received in revised form $23^{\text {rd }}$ December 2015

Accepted $27^{\text {th }}$ December 2015

Dr Anna Łysiak-Łątkowska

Instytut Historii

Uniwersytet Gdański

e-mail:hisall@ug.edu.pl 


\section{ALPHONSE-MARIE FORTIA DE PILES I LOUIS DE BOISGÉLIN DE KERDU, PODRÓŻUJĄCY EMIGRANCI PO KRAJACH NIEMIECKICH I DANII W KOŃCU XVIII WIEKU}

\section{Streszczenie}

Słowa kluczowe: relacja, warunki podróży, drogi, zbiory i kolekcje, biblioteki, pałace, zamki

W artykule, na podstawie Voyage de deux Français en Allemagne, Danemark, Suède, Russie et Pologne, fait en 1790-1792 autorstwa A.-M. Fortiade de Piles, L. de Boisgélin de Kerdu został zaprezentowany obraz krajów Rzeszy niemieckiej i Danii z końca XVIII w. Poruszone zostały zagadnienia dotyczące oceny warunków podróżowania, przedstawione zostały opisy mijanych miejsc. W artykule została zwrócona uwaga na charakterystyczne elementy relacji podróżniczej jako formy przekazu, jak i na refleksje i wrażenia, które nadawały jej indywidualny kształt.

\section{ALPHONSE DE FORTIA DE PILES UND LOUIS DE BOISGÉLIN DE KERDU, ZWEI REISENDE EMIGRANTEN DURCH DEUTSCHLAND UND DÄNEMARK AM ENDE DES 18. JAHRHUNDERTS}

\section{Zusammenfassung}

Schlüsselwörter: Bericht, Reisebedingungen, Wege, Sammlungen, Bibliotheken, Paläste, Schlösser

Der Artikel bietet ein Bild von den Territorien des Deutschen Reiches und von Dänemark am Ende des 18. Jahrhunderts nach der Voyage de deux Français en Allemagne, Danemark, Suède, Russie et Pologne, fait en 1790-1792 von Alphonse-Marie Fortiade de Piles und Louis de Boisgélin de Kerdu. Dabei geht es um Urteile über die Qualität des Reisens, und es werden Beschreibungen von Orten wiedergegeben, durch die man kam. Der Artikel verweist auf die spezifischen Elemente des Reiseberichts als einer Berichtsform wie auf die Reflexionen und Eindrücke, die ihm seine individuelle Form geben. 